Issue 2/2017

\title{
THE ECONOMIC IMPACT ON GLOBAL TOURISM
}

\author{
Bogdan SOFRONOV ${ }^{1}$ \\ ${ }^{1}$ University Politehnica of Bucharest, Splaiul Independenței 313, Bucharest \\ 060042, Romania, Email: boghy.official@yahoo.com
}

\begin{abstract}
Tourism is an important economic activity in most countries around the world. As well as its direct economic impact, the industry has significant indirect and induced impacts.

The outlook for the tourism sector in 2017 remains robust and will continue to be at the forefront of wealth and employment creation in the global economy, despite the emergence of a number of challenging headwinds.

In tourism, GDP growth is expected to accelerate to 3.8\%, up from $3.1 \%$ in 2016. As nations seem to be looking increasingly inward, putting in place barriers to trade and movement of people, the role of tourism becomes even more significant, as an engine of economic development and as a vehicle for sharing cultures, creating peace, and building mutual understanding.
\end{abstract}

Keywords: economic impact; tourism; global tourism; travel; tourism economics.

JEL Classification: $Z_{30}, Z_{32}$

\section{Introduction}

The main objective of the research: the economic impact on global tourism is to provide, on a basis-consistent, reliable, comparable data and to assess tourism contribution to national economic activity. [Economic Impact Research, 2017]

Over the longer term, growth of tourism sector will continue to be strong so long as the investment and development take place in an open and sustainable manner. Enacting pro-growth travel policies that share benefits more equitably can foster a talent and business environment necessary to enable tourism to realize its potential. In doing so, not only can we expect the sector to support over 380 million jobs by 2027, but it will continue to grow its economic contribution, providing the rationale for the further protection of nature, habitats, and biodiversity. [Economic Impact World, 2017] 


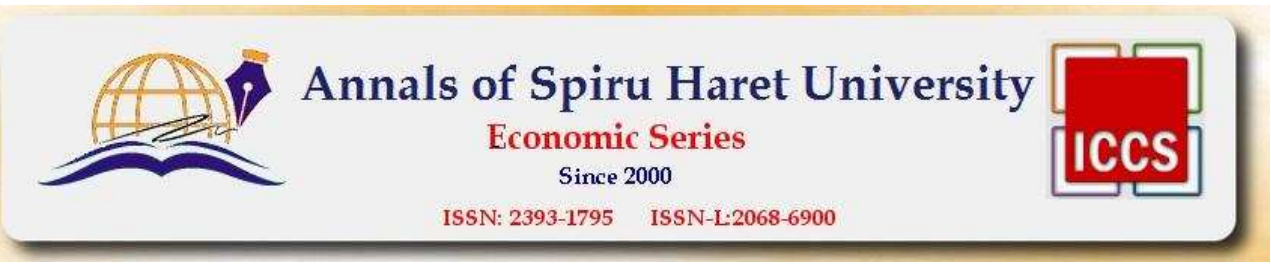

Issue $2 / 2017$

Tourism is a key sector for economic development and job creation throughout the world. In 2016, tourism directly contributed US\$2.3 trillion and 109 million jobs worldwide. Taking its wider indirect and induced impacts into account, the sector contributed US\$7.6 trillion to the global economy and supported 292 million jobs in 2016. This was equal to $10.2 \%$ of the world's GDP, and approximately 1 in 10 of all jobs. [Global Economic Impact and Issues, 2017]

Tourism's impact includes people travelling for both leisure and business, domestically and internationally. In 2016, $76.8 \%$ of all travel spend was as a result of leisure travel, compared to $23.2 \%$ from business travel. [Global Economic Impact and Issues, 2017]

Domestic travel generated $72 \%$ of the sector's contribution to GDP, thus making a significantly larger contribution than international travel, with foreign visitor spending at 28\%. [Global Economic Impact and Issues, 2017]

Tourism is an export sector, attracting foreign spending to a country in the form of international visitors. In 2016, global visitor exports accounted for $6.6 \%$ of total world exports (a total of US\$1.4 trillion) and almost $30 \%$ of total world services exports. [Global Economic Impact and Issues, 2017]
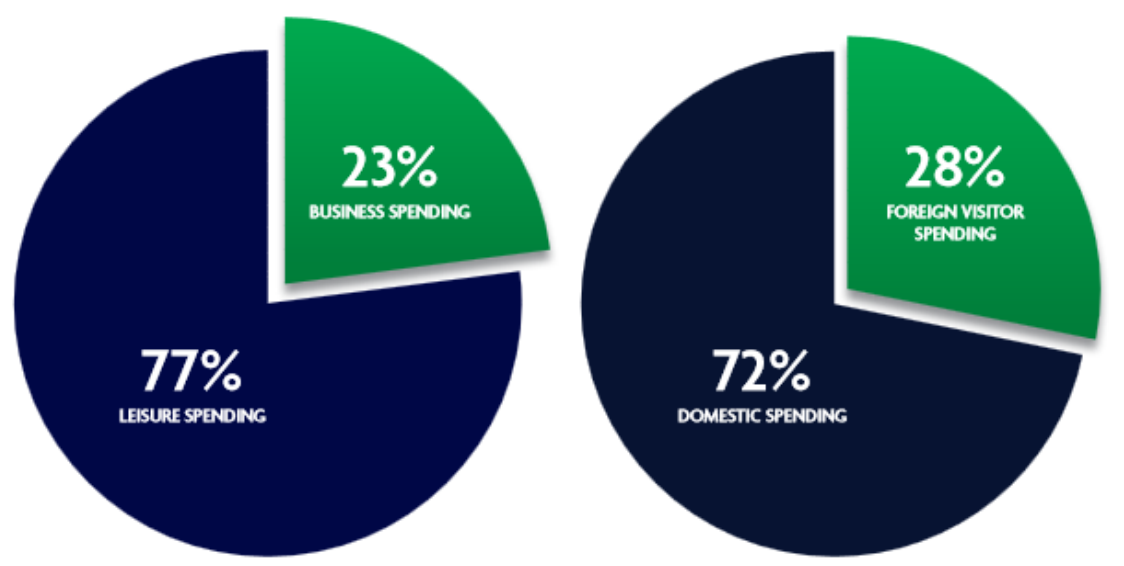

Figure no. 1. Business vs Leisure / Domestic vs Foreign Spending

Source: "Global Economic Impact and Issues (2017)," World Travel \& Tourism Council, accessed May 4, 2017, https://www.wttc.org/-/media/files/reports/economic-impactresearch/2017-documents/global-economic-impact-and-issues-2017.pdf), p. 3 


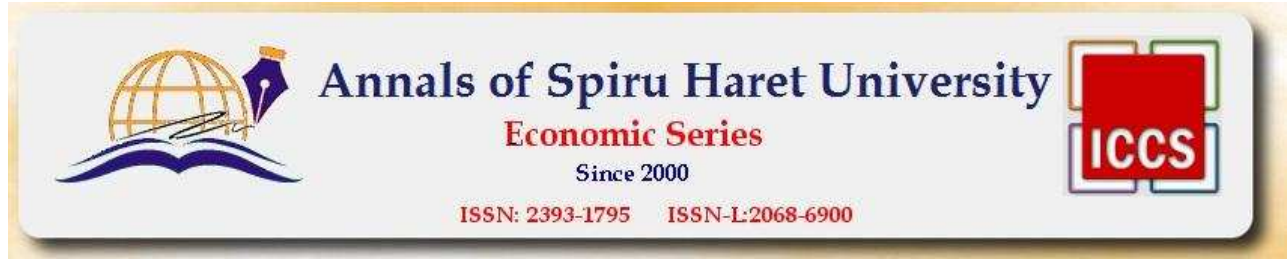

Issue $2 / 2017$

\section{Literature review}

My research paper entitled: The economic impact on global tourism, is written after I've documented on the basis of the following published articles:

1. Economic Impacts Analysis written and published by World Travel and Tourism Council.

2. Economic Impacts of Tourism Industry written by Fateme Tohidy Ardahaey published on International Journal of Business and Management.

3. The Economic Impacts of Tourism: A Special Issue written by Timothy J. Tyrell and Robert J. Johnston published on Journal of Travel Research.

\section{Tourism's contribution to the world's economy}

Tourism's direct contribution to GDP grew by $3.1 \%$ in 2016. This was faster than the global economy as a whole which grew at $2.5 \%$, meaning that, for six consecutive years, the tourism sector has outperformed the global economy. [Global Economic Impact and Issues, 2017]

The direct contribution of tourism to employment grew by $1.8 \%$ in 2016 meaning almost 2 million net additional jobs were generated directly by the sector, and a total of around 6 million new jobs created as a result of total direct, indirect and induced activity. This means that almost 1 in 5 of all new jobs created in 2016 was linked to tourism. [Global Economic Impact and Issues, 2017]

In addition to outpacing global economic growth, the tourism sector also outperformed several other major global economic sectors in 2016. Specifically, direct tourism GDP growth was stronger than the growth recorded in the financial and business services, manufacturing, public services, retail and distribution, and transport sectors, but was marginally slower than growth in the communications sector. [Global Economic Impact and Issues, 2017]

In 2017, the total contribution of tourism to the world's economy is forecast to grow by $3.5 \%$. Continued solid growth at a global level is expected across the main economic indicators of GDP contribution, job creation, investment, and visitor exports, with visitor exports making an especially strong contribution. [Global Economic Impact and Issues, 2017]

A key challenge for tourism in 2017 will be a general slowdown in consumer spending power, which will impact consumer spending on tourism. The combination of higher inflation caused by recovering oil prices (which could have knock-on impacts for air fares), rising debt servicing costs as interest rates rise, and a slowdown in job creation across the globe is curbing global spending power 


\section{Issue $2 / 2017$}

which is expected to grow at the weakest rate for eight years in 2017. [Global Economic Impact and Issues, 2017]

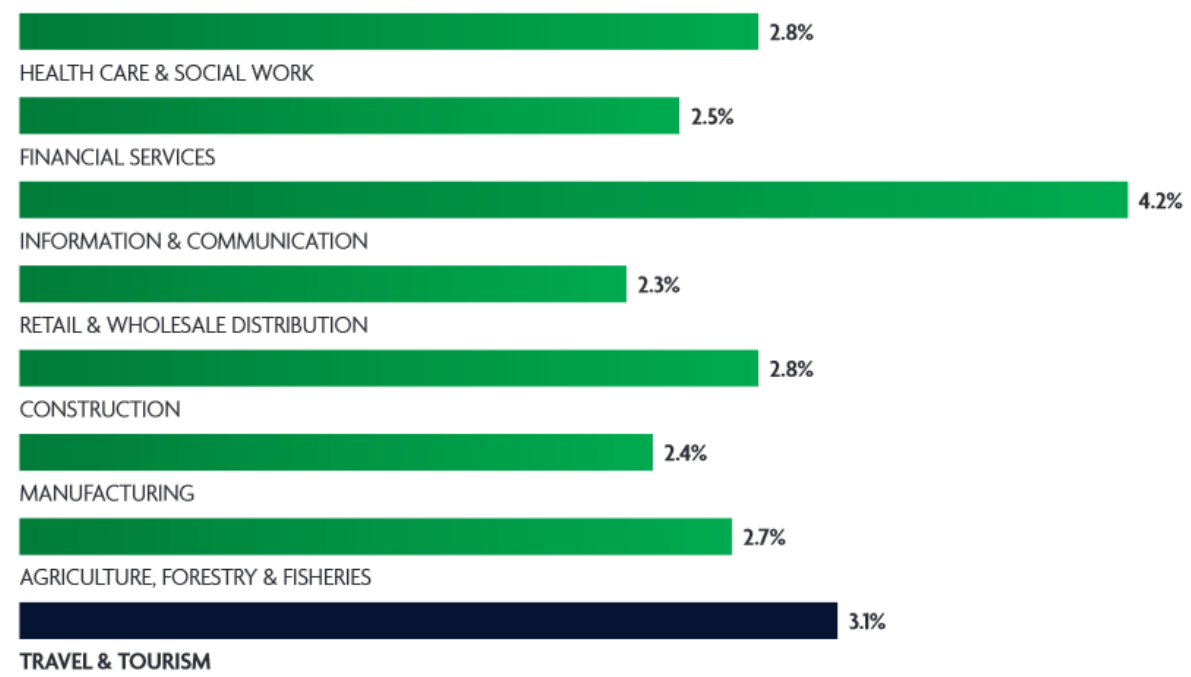

Figure no. 2. World industry GDP growth

Source: "Global Economic Impact and Issues (2017)," World Travel \& Tourism Council, accessed May 4, 2017, https://www.wttc.org/-/media/files/reports/economic-impactresearch/2017-documents/global-economic-impact-and-issues-2017.pdf), p. 3

The outlook, however, varies across the different outbound markets [Global Economic Impact and Issues, 2017]:

- With the dollar strength expected to persist, 2017 is forecast to be another strong year for the USA, with growth of $5.4 \%$ in outbound tourism spend expected. The most likely beneficiaries of this strong growth will be other North American destinations such as Canada and Mexico, as well as Caribbean and Mediterranean destinations.

- In China, after 7 consecutive years of annual growth in excess of $20 \%$, outbound spending is expected to cool slightly, yet remain very strong by international standards, with growth of $12.0 \%$ expected in 2017.

- The depreciation of sterling is forecast to continue during 2017, which is expected to lead to a substantial slowdown in outbound tourism spending growth 


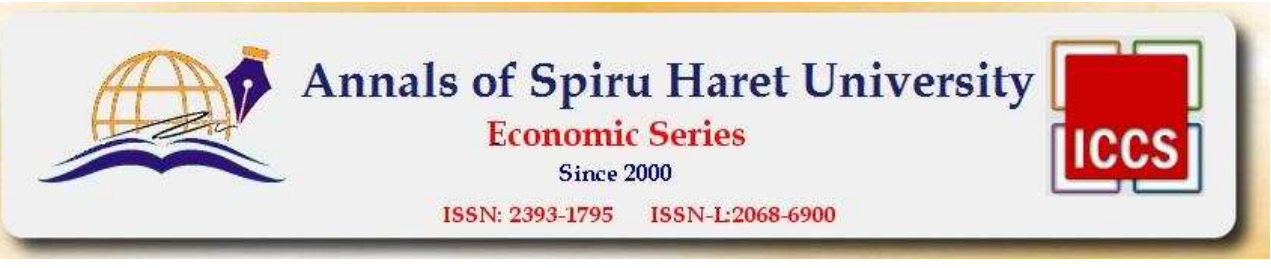

Issue $2 / 2017$

from the UK, from $8.0 \%$ in 2016 to a contraction of $4.2 \%$ in 2017 . The markets most likely to suffer as a consequence are European destinations and longer-haul travel to the USA.

Tourism's direct contribution to GDP is expected to grow at an average of $3.9 \%$ per year over the next ten years. [Global Economic Impact and Issues, 2017]

By 2027, tourism is expected to support more than 380 million jobs globally, which equates to 1 in 9 of all jobs in the world and the sector is expected to contribute around $23 \%$ of total global net job creation over the next decade. Meanwhile, total tourism GDP is expected to account for $11.4 \%$ of global GDP and global visitor exports are expected to account for $7.1 \%$ of total global exports. [Global Economic Impact and Issues, 2017]

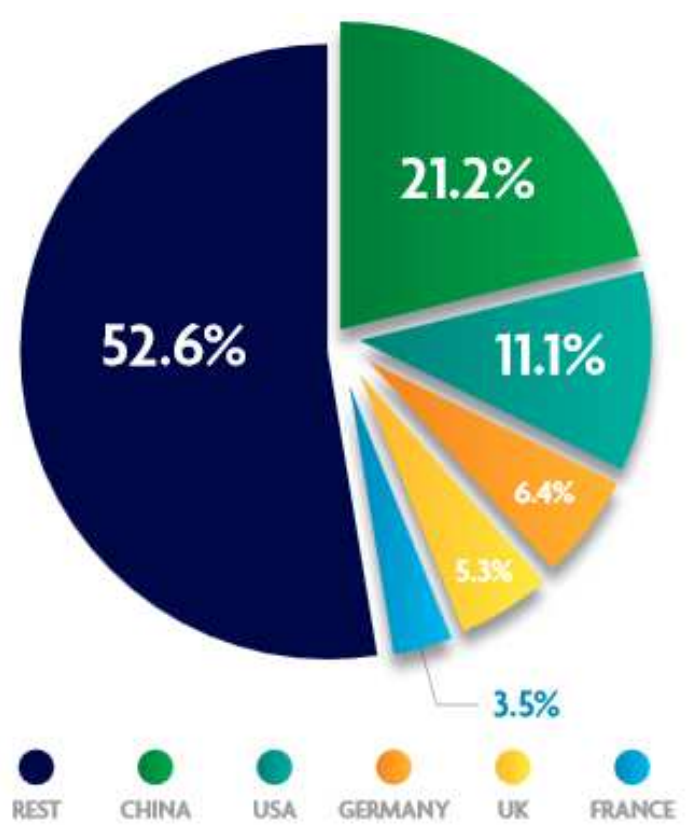

Figure no. 3. Outbound travel expenditure by country

Source: "Global Economic Impact and Issues (2017)," World Travel \& Tourism Council, accessed May 4, 2017, https://www.wttc.org/-/media/files/reports/economic-impactresearch/2017-documents/global-economic-impact-and-issues-2017.pdf), p. 4 
Issue 2/2017

Furthermore, the sector is expected to outperform the global economy throughout the forecast period and increase its share of global economic activity across each of GDP, employment, exports and investment. [Global Economic Impact and Issues, 2017]

In addition to outperforming the global economy over the next ten years, tourism is also forecast to outpace a range of other major global economic sectors, including communications, financial and business services, manufacturing and retail and distribution. [Global Economic Impact and Issues, 2017]

In 2017, all world sub-regions are expected to experience growth in direct tourism GDP. South East Asia and South Asia are expected to be the fastest growing world regions with growth of around $6.5-7 \%$. This year is also expected to mark a turnaround in fortunes for Latin America (2.0\%) and North Africa $(2.8 \%)$ as modest growth returns after weakness in 2016. [Global Economic Impact and Issues, 2017]

South Asia is expected to be the fastest growing world region over the next 10 years, with average annual direct tourism GDP growth of $6.7 \%$ expected, with strong growth in India (6.8\%), the driving force. In China long term annual average growth of $7.5 \%$ is expected, with the tourism sector being increasingly viewed as a high-potential priority sector by authorities, which has led to an upgrade in our long-term tourism investment forecast. Northeast Asia overall is forecast to grow by $5.9 \%$ per year, ahead of Southeast Asia, where average annual growth of $5.7 \%$ is expected. The next tier of sub-regions, with growth in the 3-5\% bracket include Sub-Saharan Africa (4.8\%), the Middle East (4.6\%), North Africa (4.0\%), the Caribbean (3.6\%), Latin America (3.5\%) and North America (3.2\%). Slower, yet robust growth is expected in Oceania (2.9\%) and Europe (2.4\%). [Global Economic Impact and Issues, 2017]

Countries showing strong international tourism growth [Global Economic Impact and Issues, 2017]:

Tourism has been outpacing the global economy for the past six years, which is reflected in the growth figures for individual countries as well. Several countries have shown especially dramatic growth in visitor exports over this time period. They have seen significantly increased inflow of tourism spending, thanks to prioritisation of tourism, opening borders, infrastructure investment, and promotional efforts, among other factors. 


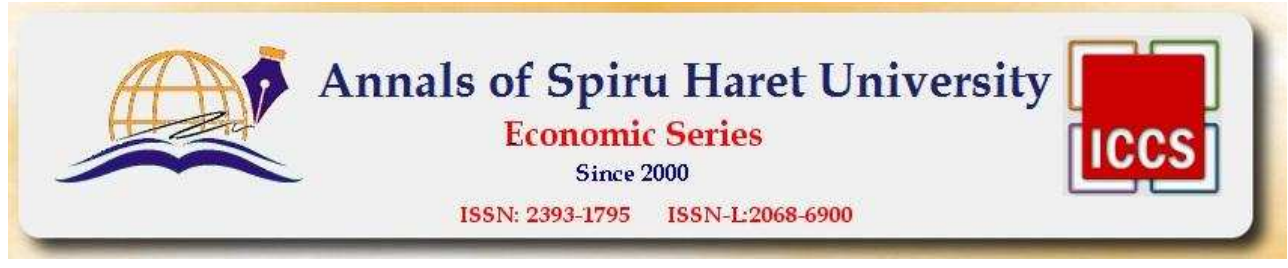

Issue $2 / 2017$ 2017]:

Countries performed best in 2016 [Global Economic Impact and Issues,

At country level, amongst the fastest growing tourism economies in 2016 and buoyed by strong inbound international visitor spending were Azerbaijan (46.1\%), Mongolia (24.4\%), Iceland (20.1\%), Cyprus (15.4\%), Kazakhstan (15.2\%), Moldova (14.2\%), Costa Rica (12.1\%), Georgia (11.2\%), Sri Lanka (10.7\%), and Thailand (10.7\%), which grew even more strongly than fast growth markets like India (8.5\%), China (8.1\%), and Indonesia (5.8\%). 2017]:

Tourism outperforming economy [Global Economic Impact and Issues,

At country level, direct tourism GDP growth also outpaced economy-wide GDP growth in 116 of the 185 countries covered by this research. [Global Economic Impact and Issues, 2017]

Bulgaria, Cyprus, Iceland, Qatar, and Thailand are some of the countries which saw their tourism sectors outperform the general economy most significantly. [Global Economic Impact and Issues, 2017]

G20 countries whose tourism performed better than the economy as a whole in 2016 include Australia, Canada, China, India, Mexico and South Africa. [Global Economic Impact and Issues, 2017]

At country level, the fastest growing larger tourism countries are expected to be China, India, Thailand, and Indonesia. By 2027, China is expected to have overtaken the USA in terms of total tourism GDP, domestic tourism spending and investment. However, the USA is expected to remain on top in terms of direct tourism GDP, visitor exports and business travel spending. [Global Economic Impact and Issues, 2017]

India is expected to establish itself as the fourth largest tourism economy by 2027 , both in terms of direct and total GDP, only behind China, the USA and Germany. Thailand is expected to continue its fast-paced growth and become the third largest market for visitor exports by 2027, taking over Spain, which is expected to drop to fourth place. Other notable countries expected to move up the tourism GDP rankings considerably by 2027 include Qatar, UAE, and Vietnam. [Global Economic Impact and Issues, 2017]

Amongst the smaller economies, Kyrgyzstan, Namibia, Myanmar, and Rwanda are expected to be star performers in terms of tourism growth to 2027 . [Global Economic Impact and Issues, 2017]

In 2017, the economic fallout from the Brexit vote is expected to have diverging implications for domestic and international tourism spending. Due to 


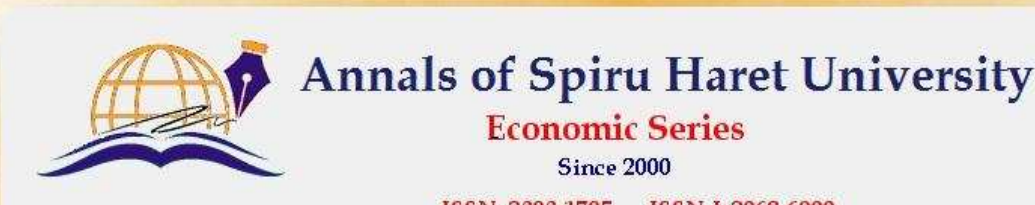

ISSN: 2393-1795 ISSN-L:2068-6900

Issue 2/2017

higher inflation and weakened consumer spending prospects, the domestic tourism spending outlook has been downgraded. At the same time, the depreciated value of sterling should provide a boost to inbound international spending. Outbound tourism spending from the UK was very strong in 2015 and 2016, but should slow considerably in 2017 through a combination of the weaker consumer outlook and the exchange rate depreciation, with the latter expected to switch some demand from international to domestic. Overall, direct tourism GDP growth in the UK is expected to slow to $2.9 \%$ in 2017, down from $3.2 \%$ last year. [Global Economic Impact and Issues, 2017]

\section{The economic impact on world tourism}

The direct contribution of tourism to GDP reflects the 'internal' spending on tourism (total spending within a particular spending by government on tourism services directly linked to visitors, such as cultural or recreational. [Economic Impact World, 2017]

The direct contribution of tourism to GDP is calculated to be consistent with the output, as expressed in National Accounting of tourism-characteristic sectors such as hotels, airlines, airports, travel agents and leisure and recreation services that deal directly with tourists. The direct contribution of tourism to GDP is calculated from total internal spending by 'netting out' the purchases made by the different tourism sectors. This measure is consistent with the definition of tourism GDP. [Economic Impact World, 2017]

The total contribution of tourism includes its 'wider impacts' (i.e. the indirect and induced impacts) on the economy. The 'indirect' contribution includes the GDP and jobs supported by [Economic Impact World, 2017]:

- tourism investment spending - an important aspect of both current and future activity that includes investment activity such as the purchase of new aircraft and construction of new hotels;

- government 'collective' spending, which helps tourism activity in many different ways as it is made on behalf of the 'community at large' - e.g. tourism marketing and promotion, aviation, administration, security services, resort area security services, resort area sanitation services;

- domestic purchases of goods and services by the sectors dealing directly with tourists - including, for example, purchases of food and cleaning services by hotels, of fuel and catering services by airlines, and IT services by travel agents. 

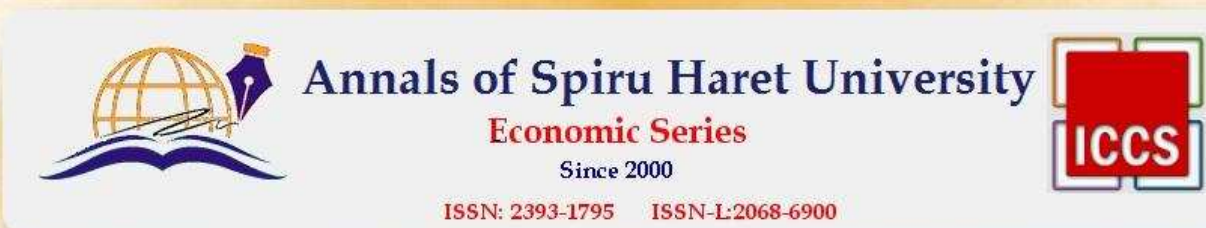

ISSN: $2393-1795 \quad$ ISSN-I.2068-6900

Issue $2 / 2017$

Tourism's contribution to employment [Economic Impact World, 2017]:

Tourism generated $108,741,000$ jobs directly in 2016 (3.6\% of total employment) and this is forecast to grow by $2.1 \%$ in 2017 to $111,013,000$ (3.6\% of total employment). This includes employment by hotels, travel agents, airlines and other passenger transportation services (excluding commuter services). It also includes, for example, the activities of the restaurant and leisure industries directly supported by tourists.

By 2027, tourism will account for 138,086,000 jobs directly, an increase of $2.2 \%$ pa over the next ten years.

The total contribution of tourism to employment was $292,220,000$ jobs in 2016 (9.6\% of total employment). This is forecast to rise by $1.9 \%$ in 2017 to $297,896,000$ jobs ( $9.7 \%$ of total employment).

By 2027 , tourism is forecast to support $381,700,000$ jobs $(11.1 \%$ of total employment), an increase of $2.5 \%$ pa over the period.

Visitor exports [Economic Impact World, 2017]:

Money spent by foreign visitors to a country (or visitor exports) is a key component of the direct contribution of tourism. In 2016, the world generated USD1,401.5bn in visitor exports. In 2017, this is expected to grow by $4.5 \%$, and the world is expected to attract 1,290,780,000 international tourist arrivals.

By 2027, international tourist arrivals are forecast to total 2,042,420,000, generating expenditure of USD2,221.0bn, an increase of $4.3 \%$ pa.

Investment [Economic Impact World, 2017]:

Tourism is expected to have attracted capital investment of USD806.5bn in 2016. This is expected to rise by $4.1 \%$ in 2017 , and rise by $4.5 \%$ pa over the next ten years to USD1,307.1bn in 2027.

Tourism's share of total national investment will rise from $4.5 \%$ in 2017 to $5.0 \%$ in 2027.

Different components of tourism [Economic Impact World, 2017]:

Leisure travel spending (inbound and domestic) generated $76.8 \%$ of direct tourism GDP in 2016 (USD3,822.5bn) compared with $23.2 \%$ for business travel spending (USD1,153.6bn).

Leisure travel spending is expected to grow by $3.9 \%$ in 2017 to USD3,970.4bn, and rise by $4.1 \%$ pa to USD5,917.7bn in 2027 . 


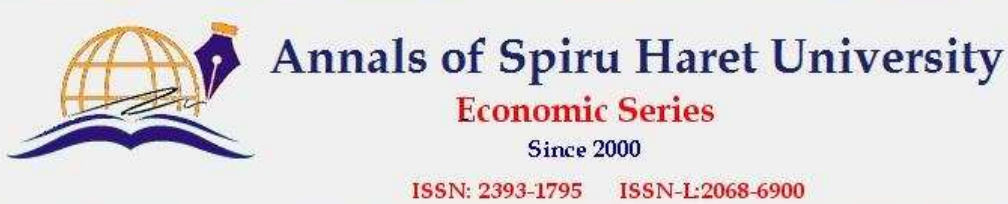

Issue 2/2017

Business travel spending is expected to grow by $4.0 \%$ in 2017 to USD1,199.7bn, and rise by $3.7 \%$ pa to USD1,719.9bn in 2027.

Domestic travel spending generated $71.8 \%$ of direct tourism GDP in 2016 compared with $28.2 \%$ for visitor exports (i.e. foreign visitor spending or international tourism receipts).

Domestic travel spending is expected to grow by $3.7 \%$ in 2017 to USD3,705.4bn, and rise by $3.9 \%$ pa to USD5,414.1bn in 2027 .

Visitor exports are expected to grow by $4.5 \%$ in 2017 to USD1,464.4bn, and rise by $4.3 \%$ pa to USD2,221.0bn in 2027.

\section{The economic impact on global tourism: results}

The UK formally began the process of leaving the EU after triggering Article 50 at the end of March. In response, the European Council has published guidelines on how the EU will respond to the UK's departure. These guidelines indicate that trade discussions could begin before exit terms have been fully agreed but that trade discussions will not be held until "sufficient progress" has been made on the exit agreement. There is also a likelihood of a slow start to the UK-EU discussions due to the forthcoming elections in France and Germany. Published data indicated that UK GDP grew by $0.7 \%$ on Q3 and $1.8 \%$ for the whole of 2016, making the UK the second fastest growing economy amongst the G7. However, the latest data for services output in January suggests that Q1 is likely to have seen a slowdown in the pace of GDP with growth in services at $0.4 \%$ in Q1 2017, the weakest growth in two years. There has however been strong growth in the production and construction sectors in Q1 which is likely to go some way to offsetting the weakness in services. Real disposable income declined by $0.4 \%$ in $\mathrm{Q} 4$, the second consecutive quarterly fall as rising inflation continues to weigh on the consumer in 2017. But overall consumer spending is expected to grow by $1.6 \%$ this year. [Monthly Economic Impact, March, 2017]

The US economy is facing a diverse environment at present, where by stock valuations and confidence have been inflated by promised fiscal stimulus and deregulation, while the private sector remains more cautious. In Q4 2016 real GDP grew annually by $1.9 \%$, helped by consumer spending increasing by $3 \%$. However, with inflation firming to $2 \%$ in 2017 and real disposable income growth expected to slow to $2.1 \%$ in 2017 (down from $2.8 \%$ in 2016), consumer spending is expected to slow to $2.5 \%$. GDP in Q1 2017 is expected to slow to $1.0 \%$ due to weak consumer spending at the beginning of the year. Overall, the outlook for the US 


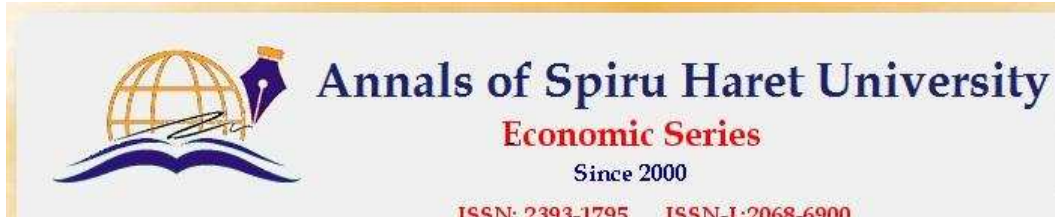

ISSN: 2393-1795 ISSN-I-2068-6900

Issue 2/2017

economy has been downgraded for 2017 , from $2.3 \%$ to $2.1 \%$, due to the weak start to 2017. [Monthly Economic Impact, March, 2017]

Euro zone growth was recorded at $0.4 \%$ in Q4 2016, bringing growth for 2016 overall to $1.7 \%$. Business surveys have indicated that an acceleration of growth is underway with quarterly growth for Q1 expected to be around $0.6 \%$. Industrial production growth of around $2 \%$ in January will be difficult to maintain with world trade growth expected to remain subdued compared to pre-financial crisis standards. Inflation in February rose to 2\%, slightly above the ECB target rate, causing real wage growth to fall from $1.2 \%$ in 2016 into negative territory at the start of 2017. The pick-up in inflation throughout the Euro zone is expected to slow household spending growth to $1.5 \%$ in 2017 compared to $1.9 \%$ in 2016. [Monthly Economic Impact, March, 2017]

Industry indicators show another year of robust growth for tourism in 2016 [Monthly Economic Impact, February, 2017]:

- Estimates of global tourism performance across the core indicators are now available for the whole of 2016. The UNWTO World Tourism Barometer reported global growth in international tourist arrivals of $3.9 \%$ for 2016 . While this represents continued robust growth in international travel, growth was down compared to 2015, when growth of $4.6 \%$ was recorded. The fastest growing world regions for inbound international tourist arrivals in 2016 were Asia Pacific and Sub-Saharan Africa, with growth of $8.4 \%$ and $10.7 \%$ respectively. Growth was also robust in the Americas $(4.3 \%)$ but less so Europe $(2.0 \%)$ where there has been a wide divergence in performance across countries. The only world region to report negative growth in 2016 was the Middle East (-4.1\%). Significant declines in inbound arrivals to Egypt (classified as part of the Middle East according to UNWTO) largely explain this wider regional decline. Declines in inbound arrivals to large markets such as Belgium, France, Hong Kong and Turkey also explain the slowdown in global growth between 2015 and 2016.

- Global international air passenger traffic growth remained strong in 2016 with growth of $6.7 \%$, helped by continued low oil prices. This was marginally ahead of the growth of $6.6 \%$ recorded in 2015. Growth was robust across all world regions, with the strongest growth recorded in the Middle East (11.8\%), while North America was the slowest growing world region at $2.6 \%$. It should be noted that airline traffic is allocated according to the region in which the carrier is registered and should not be considered as regional traffic, which explains the divergence between 


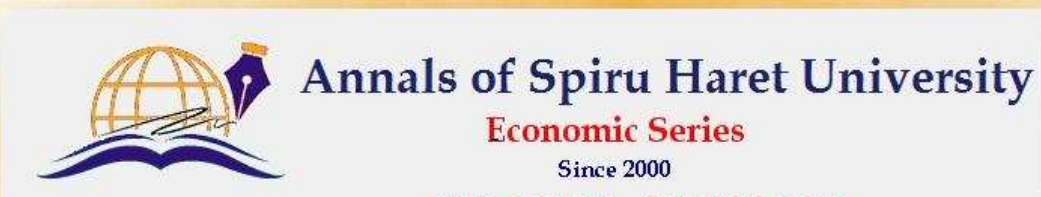

ISSN: 2393-1795 ISSN-L:2068-6900

Issue 2/2017

international tourist arrivals and international air passenger traffic growth in regions such as the Middle East.

- Hotel performance was diverse in 2016, with the Middle East experiencing declines across all key performance indicators, while regions such as Europe, North America and Sub-Saharan Africa performed much better. Hotel performance in January 2017 was again diverse across world regions. Continuing on from weakness in 2016, hotel performance has been particularly weak in the Middle East, with declines recorded again across all key performance indicators, including sharp declines in revenue per available room. However, hotel supply is expanding in the region which needs to be taken into account. In Sub-Saharan Africa and Asia Pacific declines have been recorded in occupancy rates. Meanwhile, hotel performance in North Africa has recorded significant annual growth across all key performance indicators for January 2017, compared to January 2016. Growth has also been robust across all key performance indicators in Europe, Americas and North America.

\section{Conclusions}

Tourism can bring many economic benefits, particularly in rural areas and developing countries, but mass tourism is also associated with negative effects. Tourism can only be sustainable if it is carefully managed so that potential negative effects on the host community and the environment are not permitted to outweigh the financial benefits. [Carole Simm, 2017]

The positive economic effects are [Carole Simm, 2017]:

Tourism creates jobs, both through direct employment within the tourism industry and indirectly in sectors such as retail and transportation. When these people spend their wages on goods and services, it leads to what is known as the "multiplier effect," creating more jobs. The tourism industry also provides opportunities for small-scale business enterprises, which is especially important in rural communities, and generates extra tax revenues, such as airport and hotel taxes, which can be used for schools, housing and hospitals.

The negative economic effects are [Carole Simm, 2017]:

Successful tourism relies on establishing a basic infrastructure, such as roads, visitor centres and hotels. The cost of this usually falls on the government, so it has to come out of tax revenues. Jobs created by tourism are often seasonal and poorly paid, yet tourism can push up local property prices and the cost of goods and services. Money generated by tourism does not always benefit the local community, as some of it leaks out to huge international companies, such as hotel 


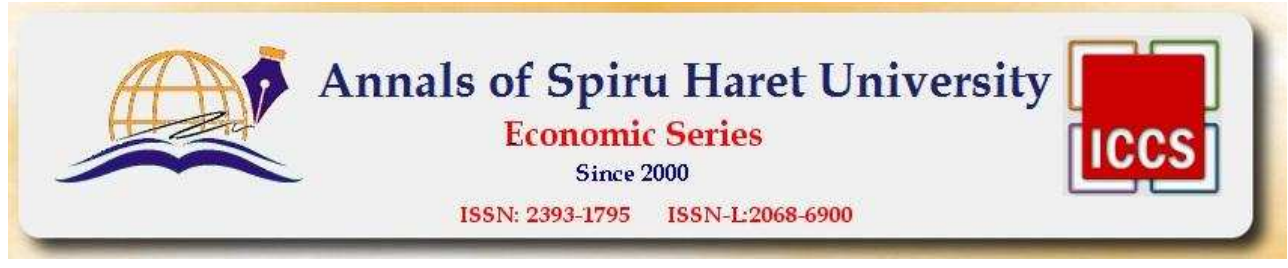

Issue $2 / 2017$

chains. Destinations dependent on tourism can be adversely affected by events such as terrorism, natural disasters and economic recession.

The direct, indirect and induced effect of tourism spending [Economic Impact World, 2017]:

- Travellers pay directly to: airlines, coaches, rental cars, trains, cruise lines, travel agents, hotels, convention centres, restaurants, shopping centres, sports arenas, entertainment, theatre, recreation.

- These are supplied by: outside goods and services such as marketing and PR, cleaning and maintenance, energy providers, catering and food production, design and print.

- Both of which create jobs: which pay salaries, wages, profits, and taxes.

- Which pay into: infrastructure, agriculture, technology, real estate, communications, education, banks, healthcare and more.

\section{References}

1. Carole Simm, "Positive \& Negative Effects of Tourism," USA Today, accessed May 3, 2017, http://traveltips.usatoday.com/positive-negative-effects-tourism-63336.html

2. "Economic Impact Research (2017)," World Travel \& Tourism Council, accessed May 2, 2017, https://www.wttc.org/-/media/files/reports/economic-impact-research/2017documents/2017_methodology-final.pdf

3. "Economic Impact World (2017)," World Travel \& Tourism Council, accessed May 3, 2017, https://www.wttc.org/-/media/files/reports/economic-impact-research/regions2017/world2017.pdf

4. "Global Economic Impact and Issues (2017)," World Travel \& Tourism Council, accessed May 4, 2017, https://www.wttc.org/-/media/files/reports/economic-impactresearch/2017-documents/global-economic-impact-and-issues-2017.pdf

5. "Monthly Economic Impact (February, 2017)," World Travel \& Tourism Council, accessed May 4, 2017, https://www.wttc.org/-/media/files/reports/monthlyupdates/monthly-report---february-2017.pdf

6. "Monthly Economic Impact (March, 2017)," World Travel \& Tourism Council, accessed May 4, 2017, https://www.wttc.org/-/media/files/reports/monthly-updates/wttcmonthly-report---march-2017.pdf 
